\title{
Reconstruction of the tower in defensive walls in Świebodzice
}

\author{
Anna Małachowicz ${ }^{1, *}$ \\ ${ }^{1}$ Wrocław University of Science and Technology, Faculty of Architecture; ul. Bolesława Prusa 53/55, \\ 50-317 Wrocław
}

\begin{abstract}
Fortification of Świebodzice, as presented in the eighteenthcentury drawings of Friedrich Bernhard Wernher, comprised one ring of walls, three gates in the form of towers with a passage on the ground floor, a rectangular gatehouse matching the height of the adjacent wall, and at least 8 rectangular towers. The entire fortification was surrounded by a moat. These architectural forms are in accordance with the oldest view over the city presented in the seventeenth-century oil painting [1]. The walls were crowned with rectangular battlements. Elements known from iconography were confirmed during research and inventory works initiated in 2007. The project, which was an aim of revitalizing the part of defensive walls along Piłsudskiego street in Świebodzice, was not only to make this relic accessible to the public (there is an observation deck in the defensive tower), but also to repair deformations formed as a result of the first restoration and because of the didactic exposition of wooden elements in the wall crowning (these elements were popular in medieval fortifications).
\end{abstract}

\section{History of Świebodzice}

The first hamlet in Świebodzice was presumably destroyed during the Mongol invasion in 1241, and the Saint Nicholas Church, consecrated by Bishop Wawrzyniec in 1228 [1], is the last remnant of this settlement. The town was granted city rights in 1279 . The castle and, according to some researchers, defensive walls, were built in Świebodzice around 1290 [2]. According to $20^{\text {th }}$ century researchers, defensive walls were erected in the first half of the $14^{\text {th }}$ century [3], which was associated with the fact that in 1331 Duke Bolko II the Small re-granted municipal rights to the town (these rights were lost in 1310). The preserved fragments of the walls do not allow drawing any unambiguous conclusions, and the site inspection conduced in the cellars of the building, in the literature identified as the ducal castle, failed to prove the presence of medieval elements. Regardless of the time of their erection, defensive walls in Świebodzice stand out due to their significant preservation, height (6-7 meters, according to Lutsch the total height amounted to 7-8 meters) [1], and a basal width of about $0.7-1$ meters.

Fortification of Świebodzice, as presented in the eighteenth-century drawings of Friedrich Bernhard Wernher, comprised one ring of walls, three gates in the form of towers with

\footnotetext{
${ }^{1}$ Corresponding author: anna.malachowicz@pwr.edu.pl
} 
a passage on the ground floor, a rectangular gatehouse matching the height of the adjacent wall, and at least 8 rectangular towers. The entire fortification was surrounded by a moat. These architectural forms are in accordance with the oldest view over the city presented in the seventeenth-century oil painting. ${ }^{2}$ The walls were crowned with rectangular battlements.

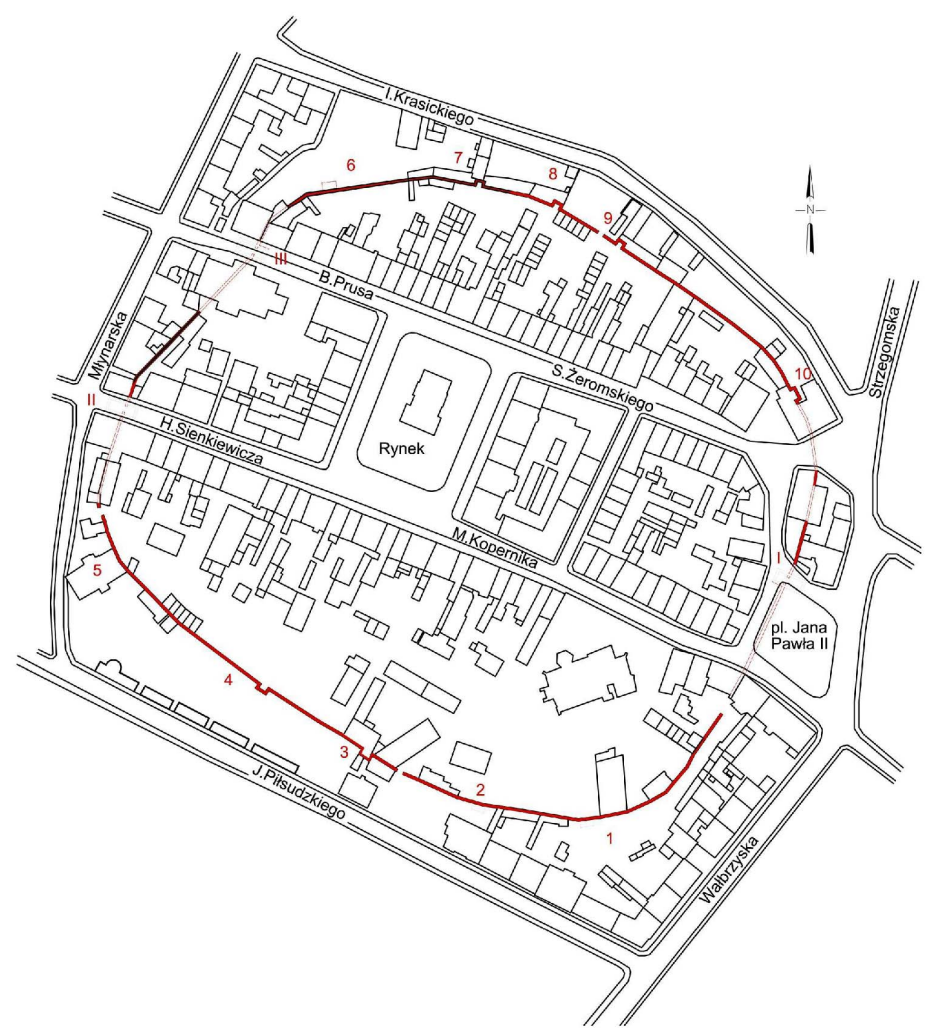

Fig. 1. Reconstruction of defensive walls in Świebodzice, drawing of the author.

\section{Study and conceptual project}

Elements known from iconography were confirmed during research and inventory works initiated in 2007. ${ }^{3}$ Remains of 10 fortified towers have been found (two locations still require archaeological confirmation). Initially, the fortified towers had the form of open shells, were higher than the adjacent wall and crowned with battlements. Over time, the towers were covered with wattle and daub and a roof. At the same time, researchers documented unique details and elements of the wall, which had not been described before, such as putlog holes with original wood on the outer face of the wall. One of the towers was probably suspended. In addition, researchers found the remains of the battlement, which helped to determine its form and height of the battlement porch. Many sites for further architectural or archaeological research were indicated in the 2007 Study.

In 2007 , besides conducting inventory works and confirming the history of defensive walls, an architectural concept for the entire wall circumference was developed [5]. The architects have proposed to reconstruct selected defensive towers with roofing and wattle and daub wall, clean and expose relics on the elevations of the buildings adjacent to

\footnotetext{
2 The painting in the Hochberg family matroneum in the Church of Peace in Świdnica

${ }^{3}$ And after the examination of the crowning of the wall during construction works in 2012.
} 
the walls, and expose the course of the wall. The concept served as a basis for discussion about the form and scope of subsequent design works, as well as research and excavation necessary to properly preserve walls.

In the conceptual project, the walls were divided into 4 sections, divided into subsections. They were formulated for individual sections of activity and the place of occurrence and the proposed way of damage repair were indicated.

The assumption of the project was:

1) the exposure of the medieval circuit of the city walls of Świebodzice and their exposure in the city landscape.

2) conservation and reconstruction of historic towers, tomb relics and fragments of the defensive wall,

3) arranging the surroundings of defensive walls,

4) providing facilities for sightseeing (towers, exit to the porch),

5) introduction of services in the surrounding of walls (Newspaper stand/shops in towers, restaurant in the basement of the former brewery).

\section{Archoelogical survey}

An archeological survey, carried out in 2008 by the archaeologist Dobiesław Karst, provided important information that confirmed the reliability of iconographic sources. According to iconography, the Świdnicka Gate consisted of a high, four-sided at the bottom tower and a pre-gate building (gatehouse). The upper part of the tower was polygonal, crowned with a high helmet. Excavation, on Jana Pawła II square, embraced a fragment of the tower and precedes the Świdnicka Gate.

The foundation of the external wall was about 2 meters thick and the porte-cochère was 6.6 meters long. Moreover, the survey confirmed the presence of a gatehouse.
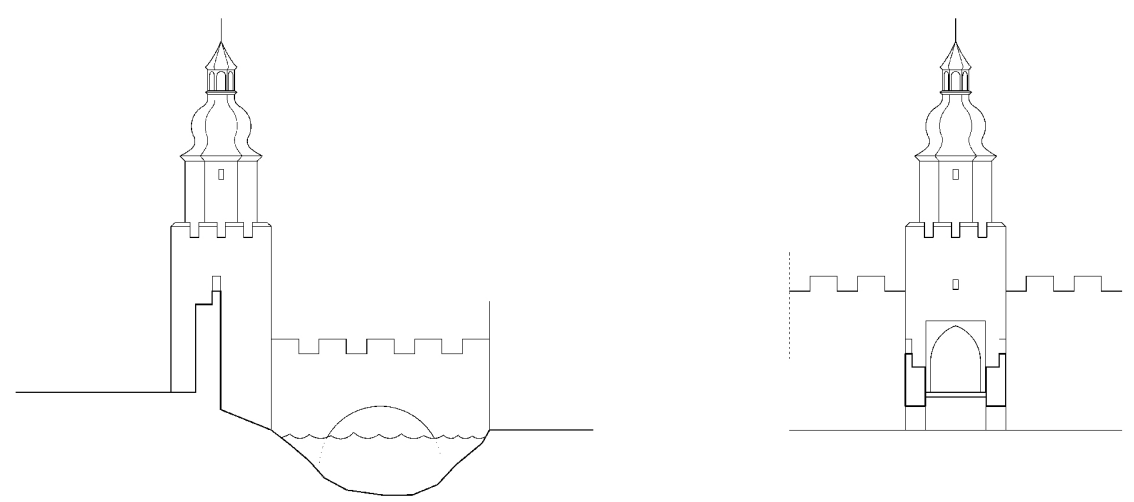

Fig. 2. Reconstruction of the architecture of Świdnicka Gate, drawing of the author.

\section{Exhibition and reconstruction projects}

Another project, developed in 2009 [6], included a well-exposed part of defensive walls along Piłsudskiego Street (today, in the place of the old moat, there is a public green space). Here, in the post-war period, the wall was incorrectly reconstructed. The preserved tower and the wall were superstructured with battlement without breastwork and of proportions inconsistent with historical data. Cement-based stony downslope was built at the level of the scarcement where the battlement porch used to be, which suggested that there was no defensive level on the wall. Moreover, cement joints were unsightly made. 


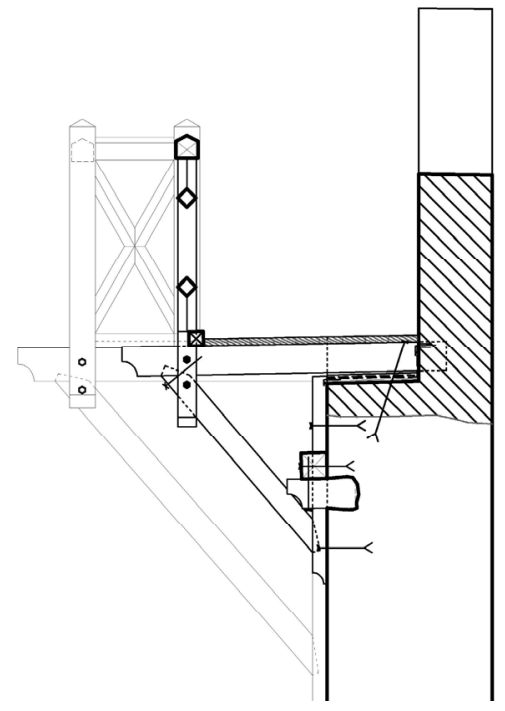

Fig. 3. Section of the battlement- exhibition concept [6].

The project also involved adjusting the battlement height $($ of $1.8 \mathrm{~m}$ ) and reconstructing the crowning, including a wooden battlement porch and high roof of the tower. Because the inside of the tower was adapted to serve as the observation deck, two external dog-legged stairs were designed to allow communication with the porch level on the wall and with the third floor of the tower. A half-shell fortified tower was closed with a wooden studwork wall from the side of the town. Replica door frame-woodwork and shutters were designed. Wooden elements (defensive platform and balustrade) were designed with simple carpentry forms in use since the Middle Ages. The project involved mounting brackets adjusted to the preserved openings in the wall - remains of the beams of the battlement porch. For safety reasons, the structure was fixed to the wall with steel anchors.

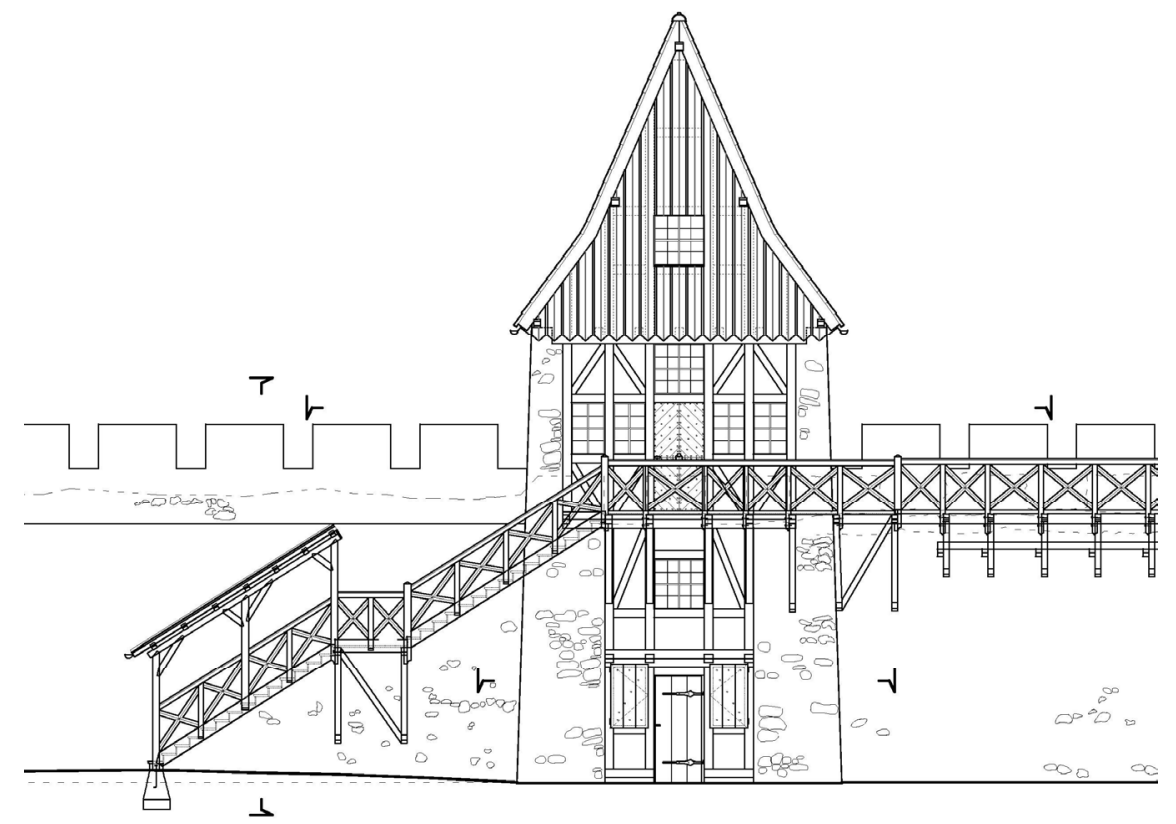

Fig. 4. Wall elevation seen from the town [6]. 
From the inside, the wall is adjacent to the area of plots occupied by re-joined tenement houses. As a result of the changes in the ownership, which were made without respecting the historical land division, the land under the buildings was sold (plots of individual tenement houses were divided by their outline), and the area in between remained the town's property. Due to the fact that entrance to the tower was designed from the inner side of the wall as well as to stop further land division, (e.g., separating small plots for freestanding garages, storage rooms, etc.) a paved pedestrian path extended at the entrance was designed along the inside face of the wall. For the same reason, the project included planting hedges to separate the walking path from the area intended for residents of tenement houses. Hedges were planted in the place of the historic defensive walls to emphasize their original layout and, in a functional way, merge former plots.

The project was updated in 2012. The new project limits land development to the pedestrian route along the wall. Construction works were carried out in the same year.

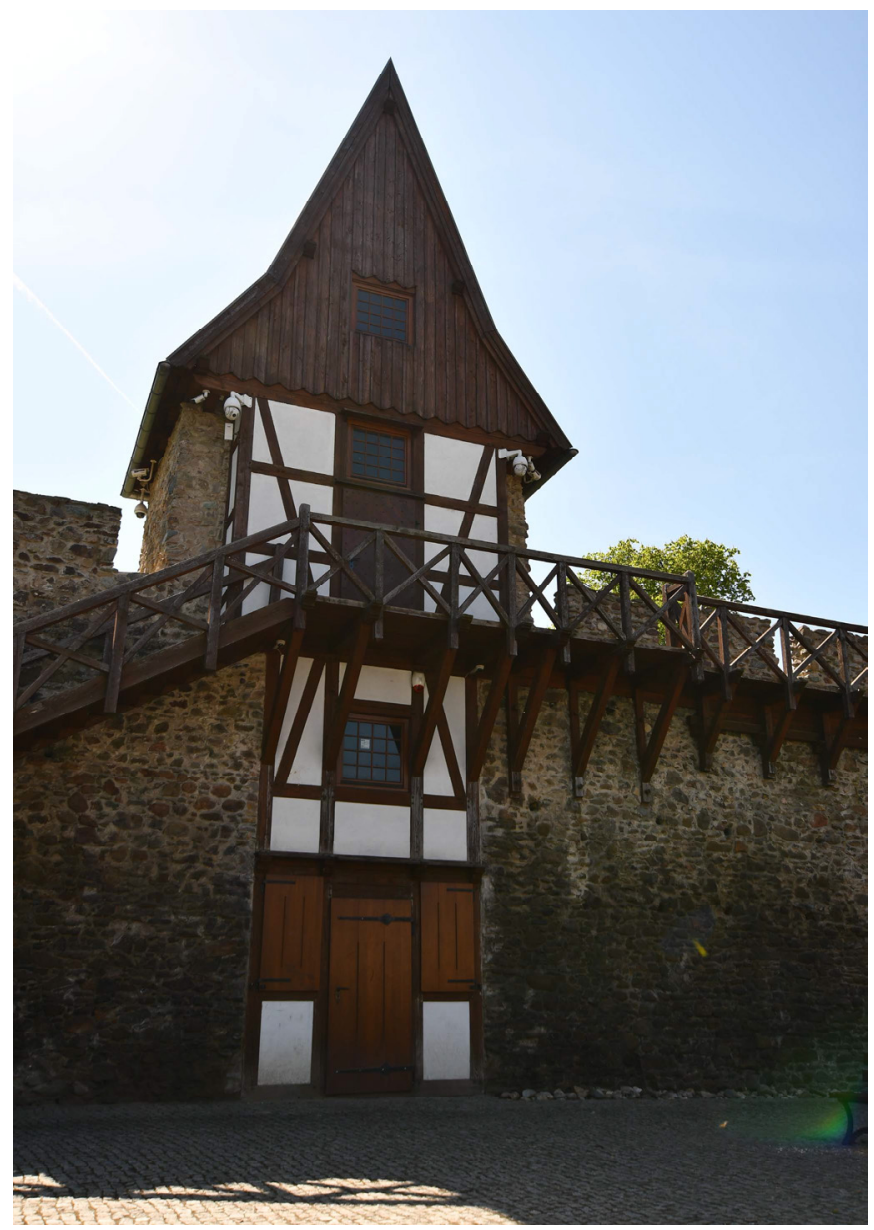

Fig. 5. Defensive wall in Świebodzice after the revitalization, author's photo.

The aim of revitalizing the part of defensive walls along Piłsudskiego street in Świebodzice was not only to make this relic accessible to the public (there is an observation deck in the defensive tower), but also to repair deformations formed as a result of the first restoration and because of the didactic exposition of wooden elements in the wall crowning (these elements were popular in medieval fortifications). 


\section{References}

1. H. Lutsch, (Verzeichnis der Kunstdenkmäler der Provinz Schlesien, [Bd. 2]: Die Kunstdenkmäler der Landkreise des Reg.-Bezirks Breslau 1889)

2. F. Zimmermann, (the fifth volume of "Beyträge zur Besschreibung von Schlesien" Brieg 1785)

3. M. Przyłęcki, (Miejskie fortyfikacje średniowieczne na Dolnym Śląsku. Ochrona, konserwacja i ekspozycja 1850-1980 [Urban medieval fortifications in Lower Silesia. Protection, conservation and exhibition 1850-1980] - Warsaw 1987)

4. Conservation and architectural study of the medieval city walls in Siwiebodzice

5. M. Małachowicz, A. Małachowicz, (Conceptual project of revitalizing of the medieval city walls and towers in Świebodzice, 2007)

6. M. Małachowicz, A. Małachowicz, I.Mądry, (A construction and executive design for the revitalization of a section of defense walls along ul. J. Pitsudski in Świebodzice, 2009) 